This item was submitted to Loughborough's Research Repository by the author.

Items in Figshare are protected by copyright, with all rights reserved, unless otherwise indicated.

\title{
Strategies for integrating the use of off-site production technologies in house building
}

PLEASE CITE THE PUBLISHED VERSION

http://dx.doi.org/10.1061/(ASCE)C0.1943-7862.0000544

\section{PUBLISHER}

(c) American Society of Civil Engineers

\section{VERSION}

AM (Accepted Manuscript)

\section{PUBLISHER STATEMENT}

This work is made available according to the conditions of the Creative Commons Attribution-NonCommercialNoDerivatives 4.0 International (CC BY-NC-ND 4.0) licence. Full details of this licence are available at: https://creativecommons.org/licenses/by-nc-nd/4.0/

\section{LICENCE}

CC BY-NC-ND 4.0

\section{REPOSITORY RECORD}

Pan, Wei, Alistair G.F. Gibb, and Andrew R.J. Dainty. 2019. "Strategies for Integrating the Use of Off-site Production Technologies in House Building”. figshare. https://hdl.handle.net/2134/17792. 


\title{
Strategies for integrating the use of offsite production technologies in housebuilding
}

\author{
Wei Pan ${ }^{1}$, Alistair G. F. Gibb ${ }^{2}$ and Andrew R. J. Dainty, M.ASCE ${ }^{3}$
}

\begin{abstract}
Despite extensive research into attitudes and practice surrounding the uptake of offsite production technologies, there is limited understanding of how best to integrate their use into business processes at organizational level. Drawing on an action-research case study with a leading UK housebuilding organization this paper scrutinizes the processes through which offsite technologies were adopted and utilized. The use of offsite was fundamentally framed by the key stages and business milestone reviews of the housebuilding process, which together represented a complex and multi-layered structure of business management. Five offsite reviews were aligned with the business processes. Strategies for integrating the use of offsite technologies are examined. It was crucial to establish an overall offsite strategy and integrate it into the process from land acquisition on. Organizational learning embraced the adoption of offsite, while extra reporting and management efforts introduced bureaucracy. Culture change was commonly perceived difficult and painful. Earlier engagement with supply chains was advocated for favoring the offsite approach and improving business efficiency, whilst it also demanded greater commitment of the housebuilder to specific supply chains and therefore exposed the business to risks associated with planning and market changes. The strategies should facilitate building companies’ strategic management of offsite technology.
\end{abstract}

CE Database subject headings: Offsite production; Prefabrication; Process; Strategy; United Kingdom; Housebuilding; Construction management.

\footnotetext{
${ }^{1}$ Reader, School of Architecture, Design and Environment, University of Plymouth, Plymouth, Devon, PL4 8AA, UK Email: wei.pan@plymouth.ac.uk

${ }^{2}$ Professor, Department of Civil and Building Engineering, Loughborough University, Loughborough, LE11 3TU, UK Email: a.g.gibb@lboro.ac.uk

${ }^{3}$ Professor, Department of Civil and Building Engineering, Loughborough University, Loughborough, LE11 3TU, UK Email: a.r.j.dainty@lboro.ac.uk
} 


\section{Introduction}

The past few decades have seen increasing interest in adopting and utilizing offsite production technologies in housebuilding in many countries and regions. Reported examples include the development of 'prefabricated house building' in Japan (Barlow and

Ozaki 2005; Gann 1996), ‘offsite manufacturing housing’ in Germany (Venables and Courtney 2004), ‘industrialized building’ in Malaysia (Kadir et al. 2006), ‘offsite manufacture' in Australia (Blismas and Wakefield 2009), 'prefabricated residential building' in Hong Kong (Jaillon and Poon 2009), ‘timber-framed multi-story buildings’ in Sweden (Mahapatra and Gustavsson 2008), ‘offsite-modern methods of construction’ in UK housebuilding (Pan et al. 2007) and 'Prefabrication, Preassembly, Modularization, and Off-site Fabrication' (PPMOF) or collectively termed as 'prework' in the US (Song et al. 2005). The benefits of using offsite technologies have also been widely studied, and include reductions in time, defects, health and safety risks, environmental impact, and whole-life cost, and a consequent increase in predictability, productivity, whole-life performance and profitability. However, most reporting on benefits resides in the context of projects (e.g. Sparksman et al. 1999; Wilson et al. 1999; Gibb and Isack 2003; Mullens and Arif 2006) or the industry as a whole (e.g. Housing Forum 2002; Parry et al. 2003; Venables et al. 2004; Eastman and Sacks 2008), whilst the offsite practice at organizational level has been largely overlooked.

The UK housebuilding market is not well-stratified; although 18,000 housebuilders are registered by the National House Building Council (Barker 2003), less than 200 companies produce more than 50 homes per year (Wellings 2006). The top 100 housebuilders together contributed almost two thirds of new homes completions in the UK (Pan et al. 2007). As such, the engagement of the larger housebuilding organizations is important to achieving a 
significant growth in the uptake of offsite technologies in order to realize their benefits. However, these large organizations are focused on eliciting profits from the development of land and the management of finance during this process rather than the actual construction process itself (Ball 1996; Barlow et al. 2003; Venables et al. 2004; Meikle 2008). Also, there is a low propensity of such firms to communicate and learn and to share knowledge and good practice within the sector (Hong-Minh et al. 2001; Roy et al. 2005). These factors, coupled with the diluting UK Government promotion of offsite following the economic recession and the consequent Government spending review (TSO 2010), have inhibited a wider take-up of offsite technologies in UK housebuilding. Nevertheless, the sustainability and 'zero carbon' agenda, primarily featured in the Code for Sustainable Homes and carbon emissions reduction by $80 \%$ by 2050 (CLG 2007), act as a main driver for the future of offsite in UK housebuilding (Goodier and Pan 2010; Ball 2010). Thus, organizations which do not have innovative sustainable technology management strategies in place are likely to be exposed to both technical and business risks.

In addressing such a knowledge gap at organizational level this paper scrutinizes the processes through which offsite technologies were adopted and utilized in housebuilding. The examination was carried out through a critical survey of the literature and an actionresearch case study with a leading UK housebuilding organization. Strategies for integrating the use of offsite production technologies are identified and examined. The paper then discusses the results in three evaluation contexts including diverse business models, various types of offsite technology and different countries. The discussion offers a point of departure for other organizations seeking to benefit from better utilization of offsite methods, and facilitates their strategic management of technological innovation. 


\section{Classifying offsite production technologies}

Offsite production is the manufacture and preassembly of building components, elements or modules before installation into their final locations (Goodier and Gibb 2007). There are many terms in use, often interchangeably for offsite production. These terms can be grouped, by affix, under four categories: 'offsite', e.g. offsite construction / fabrication / manufacturing; ‘pre’, e.g. preassembly, prefabrication, prework; ‘modern’, e.g. modern methods of construction; and 'building', e.g. system building, non-traditional building, industrialized building. This paper acknowledges subtle differences between these terms and their contexts of use, which however are out of the scope of the paper. The general term 'offsite production' is used in the paper for consistency. In relation to the degree of offsite work, offsite production technologies can be categorized into four levels (Gibb and Pendlebury 2006):

- component and subassembly, i.e. elements always made in factory and never considered for on-site production, e.g. lintels;

- non-volumetric preassembly, i.e. preassembled units which do not enclose usable space, e.g. precast concrete wall panels;

- volumetric preassembly, i.e. preassembled units which enclose usable space and are typically fully factory finished internally but do not form the building structure, e.g. bathroom pods;

- modular building, i.e. preassembled modules which together form the whole building, e.g. hotel modules.

\section{Offsite production in housebuilding}

Despite acknowledged multi-faceted benefits from offsite approaches, their uptake in the UK industry remains slower than it could be. The market value of offsite in UK 
construction is hard to determine, but has been estimated up to £6bn (see Taylor 2010), equivalent to a less than $6 \%$ share in UK construction with an annual output worth over £100bn (BERR 2008). A recent survey of leading UK housebuilders by Pan et al. (2008) confirmed that the level of overall application of offsite in housebuilding was also low. They found that some highly documented offsite techniques, including complete modular building, bathroom/toilet and kitchen pods and flat packs, plant modules, and complete wall panels, actually only applied to a very limited extent in housing. Although more than half of the participating housebuilders were planning to increase their use of offsite (by volume) by around one-fifth on average, these firms were still concerned about the risk associated with the use of offsite, particularly more complicated volumetric and complete modular techniques.

Various industry and research initiatives have attempted to investigate the use of offsite technologies, many focused on examining the attitudes and perceived drivers and barriers and/or providing recommendations on the industry level (Parry et al. 2003; Gibb and Isack 2003; Goodier and Gibb 2007; Venables et al. 2004). A general consensus from these studies is that it is less likely that the potential benefits from utilizing offsite technologies will be fully realized unless they are considered in early design stages. Pan et al. (2008) studied the perspectives of large UK housebuilders on utilizing offsite technologies, and revealed that more than two thirds of the responding firms considered the incorporation of offsite into their basic house design, whilst the rest left the incorporation of offsite to fairly late stages, such as detailed planning application and pre-construction. Many respondents explained that the early incorporation of offsite into their basic house design mainly applied to volumetric systems, modular building and some more advanced panelized systems. Offsite components, subassembly and some open panelized systems were often 
considered at later stages. Their research revealed the importance of integrating design and construction processes, supply chain management and learning in order to fully realize the benefits of offsite technologies. However, it fell short of developing the integrated processes necessary for benefits realization.

Some process maps exist, such as the RIBA Plan of Work (RIBA 2008) and the Process Protocol (Kagioglou et al. 1998), which provide a sequence of defined work stages for managing the building design and construction process. However, these process maps attempt to serve the construction industry and therefore are generic and do not address the characters of offsite production. Sacks et al. (2004) provided a useful process model for reengineering design of precast concrete products, which nevertheless fails to address corporate strategy or decision-making at the firm level. Several guidelines are available which have been produced specifically for offsite production in construction. Examples of these include the Standardization and Preassembly Guide and Toolkit for clients (Gibb 2000), Offsite Project Toolkit (Gibb and Pendlebury 2005) and tools to aid the decision process for the application of prefabrication and preassembly to building services (Wilson et al. 1999). However, none of them were devised with the specificities of housebuilding practice taken into consideration, or addressed organizational or corporate management strategy other than the project context. How these tools have promoted the take-up of offsite within housebuilding remains questionable. It is still unclear how offsite production can be integrated into the housebuilding business processes at organizational level, and what relevant strategies are needed for optimizing the use of such technologies.

\section{Methodology}

\section{Methodological framework}


Yin (2003) defined case study as a research strategy to review a specific instance, scenario or project in-depth wherein a variety of both qualitative and quantitative methods can be used in combination to generate rich datasets and robust analysis of very complex questions. He contended that case study approach is especially appropriate for exploratory research addressing 'why' and 'how' questions. There has been widespread use of case study methodology in construction engineering and management (see Taylor et al. 2011). Such an approach often sees its applications in organizational studies, for example, of reengineering the construction process in UK speculative house-building (Roy et al. 2003), of matching supply networks to Dutch modular house-building (Hofman et al. 2009), and of managing technological innovation and processes of Swedish building component manufacturers (Larsson et al. 2006).

Not all case studies are action research, but most action research is based on case study investigations (Bryman 1989). There have been various attempts of defining action research, while much of the relevant literature emphasizes the practical nature of this type of research and its main purpose to improve practice (Koshy 2005). In a broad sense, action research methodology can be defined as where researcher and members of a social (or, in the case of this study, organizational) setting collaborate in the diagnosis of a problem and in the development of a solution based on the diagnosis and where the researcher effectively becomes part of the field of study (Bryman 2008). The action research approach has also been proved effective for developing solutions to problems diagnosed, of which examples relevant to this present research are the supply chain studies in UK housebuilding (e.g. Hong-Minh et al. 2001; Naim and Barlow 2003).

\section{Action-research case study design}


Within the methodological framework outlined above, the research on which this paper reports employed an action-research case study approach. The research was part of a fouryear research program that was carried out with a leading UK housebuilding organization in two stages: 1) participant case study research in the first two years (2004-05 and 200506); and 2) action research in the rest (2006-07 and 2007-08) with the leading researcher embedded within the organization, having responsibility for offsite strategy and benefits realization within the firm. Such a combination of case study and action research that is grounded on the methodological considerations is considered effective, as it allowed not only the examination of the 'unit of analysis' or 'unit of observation' as suggested by Van de Ven (2007) (which is interpreted as offsite integration into housebuilding in this study), but the exploration of deep-seated reasons underlying business processes and decisions.

The case study company was a prominent industry player in the housebuilding sector of UK construction, which completed around 2500 new homes per annum with an annual turnover of GBP £550million at the time of the research. The research approach was based on the collaboration between the researcher and the organization, conducted using a coproduction model in creating new knowledge (Green et al. 2010). Such collaboration allowed sustained, long-term access required to undertake the work (Silverman 2005).

In order to explore how offsite production technologies are, and can best be, integrated into the housebuilding business processes, the research was designed to support the researchers to investigate and engage proactively in the use of offsite at three distinct but interrelated levels of organizational governance. First is the corporate policy level, at which the researchers examined the housebuilder's organizational context and aspirations, business processes and corporate strategies. 
Secondly, at the subsidiary firm level, the researchers investigated the implementation of corporate policy in the decision-making of using offsite technologies and actions to mobilize their supply chain towards supply chain goals. The case study company was established business for over fifty years, operating in the regions including Greater London, Northwest, Midlands, East, and Southwest of England. In the group there were five subsidiary firms: three for private housebuilding; one for special large complex projects; and the other as a social housing arm. The investigation at the subsidiary firm level was carried out with the private housebuilding subsidiary firm that operated in Northwest and West Midlands of England, based on three considerations:

- this subsidiary firm had been financially successful during recent years, which was considered attributable in part to the use of offsite technologies in their projects;

- the subsidiary firm was keen to develop strategies for optimizing the use of offsite technologies and realizing their full benefits;

- the company (the group) was seeking to benchmark the perceived good practice of the subsidiary firm with a view to rolling out an improvement program for offsite across the wider business.

Thirdly, at the project level, the researchers scrutinized the deployment of offsite technologies and their integration into the project stages. There were a number of projects carried out and planned in the subsidiary firm studied. Two of them (referred to as Projects A and B) (Table 1) were used for the examination. Both projects were located in the same geographical region, being multi-story residential buildings of 1 and 2 bedroom apartments, which were typical of the firm's business at the time. Both employed the same offsite technology, i.e. precast concrete crosswall panels (a typical offsite method of building 
construction using a series of precast concrete division or party walls which transfer the floor loads through the building to foundation; Table 1). Project A was completed in 2004, representing the firm's first and therefore exploratory use of crosswall technology, whilst Project B was completed in 2008, representing the firm's sixth and therefore established use of such technology. The project-level investigation contextualized the investigation at the subsidiary firm level in projects, and more importantly, it revealed good practice and lessons learnt of integrating offsite in housebuilding in a comparative manner.

(Insert Table 1 here)

The research design incorporating the three levels of organizational governance enabled the various factors which influence the implementation of offsite production across the different levels of governance of the company to be examined systematically. Such research design supports the development of strategies for best integrating the use of offsite technology. The hierarchy of governance (i.e. at the levels of corporate, subsidiary firm and project) reflects the business models of most large private housebuilders in the UK which operate in multi-regions under a group banner (Ball 2010; Callcutt 2007). The similar business models of the companies prompt them to perceive and take up offsite production technology in their businesses in a similar manner (Pan and Goodier 2012), which offers grounds for generalizing the results of this case study to a wider context.

\section{Data collection and analysis}

A range of data collection methods were employed to explore how offsite technologies are and can best be integrated in housebuilding. The use of multiple methods allowed gathering enough information about the cases to permit the researcher to effectively understand how the cases operated or functioned (Berg, 1998), by which a 'replication 
logic' can be generalized (Yin, 2003). The data collection methods used included: a questionnaire survey; interviews; focus groups; informal discussions; and meetings, which were supported by observations, site visits and document analysis. These methods were utilized systematically in alignment with the research design of three-level organizational governance.

- The questionnaire survey was carried out at the outset of the study to identify the organization's aspirations, concerns and practices in relation to adopting offsite technologies in their business. The participants in the survey included two senior managers of the company at the corporate level (including the roles of technical and change management), seven departmental managers at the subsidiary firm level (including the roles of land, technical, design, development, estimating, commercial, and buying), and an offsite project manager. The survey aimed to achieve an initial indication of how the business was managing the offsite implementation process.

- All the participants in the survey were subsequently interviewed on an individual basis to verify their responses to the survey and to explore any underlying considerations. The interviews also included two more roles (risk management and health \& safety) at the corporate level and the site manager of an offsite project, to complement the examination. These interviews took between half to an hour each, and enabled the identification of the company's business processes and the interviewees’ perceptions and practice of adopting and utilizing offsite technology.

- Two focus groups were run, at the two stages of this research, with participants from the corporate level of the company, which included the roles of technical, design, process, change management and external business consultant. The first focus group focused on exploring underlying considerations of the business for adopting and utilizing offsite technology, while the second mainly reviewed the integration of offsite 
into the business and examined good practice and lessons learnt. The other relevant roles of the company (including land, construction, strategic management, risk management, sustainability, sales \& marketing, and external cost consultant) were not available to attend the workshops at the time, but were accessed subsequently through separate meetings and/or informal discussion so that their opinions and practice were also captured.

- Another two focus groups were run with participants from the subsidiary firm and project levels, within the context of Projects A and B, separately. The participants covered the roles of technical, design, construction, health \& safety, buying, commercial, development and estimating in the subsidiary firm, and the project manager and the site manager. The roles of technical and change management from the corporate level also participated in these focus groups. These project-contextualized focus groups aimed to further understanding of how the strategies for utilizing offsite production were translated and enacted within the organization and projects. They also helped the researchers to achieve a deeper understanding of the decision-making process of utilizing offsite technology and learning from the projects.

Audio recording was used for the interviews and focus groups when permission from the participants was given; otherwise, notes were taken. The data collected included the company’s housebuilding business processes and activities of different departments involved, the perceptions and practice of adopting and utilizing offsite technology, good practice and learning of integrating offsite into the business processes. The data resided with a combination of completed questionnaires, interview transcripts and notes, observation notes of meetings, focus group transcripts, meeting minutes and company and project documents. The various sources of data enabled triangulation of data and 
verification of results. The analytical model (Miles and Huberman 1994) was used for data analysis, which included three concurrent flows of activity: data reduction, data display and conclusion drawing and verification.

\section{Case study results and analysis}

\section{Housebuilding business process and milestone reviews}

The business process of the case study organization was revealed very complex and multilayered. Given the focus of this paper on exploring offsite integration in housebuilding, the key stages and milestone reviews of the business process are first examined (in this section), followed by the investigation into the integration of offsite production technology into the business process (in the next section).

Four key stages of the organization’s business process was identified (Figure 1):

- 'land acquisition' stage, denoting the period from realizing a land opportunity, through initial, viability and risk assessments, submitting offer, exchanging contracts, and finally to completion on the deal. This stage involved the use of the company's (internal) design management tool to take forward initial design layouts, the creation of development appraisals, and a business milestone review.

- ' 'pre-site' stage, denoting the period from the land team handover to the development team, through agreeing on the project team, a cost plan and method of procurement, the planning design phase with associated design freezes, submittal of planning application and subsequent approval, the tender process with contract award, then the detailed design phase, and finally to start on site. This stage involved the continuous use of the company's design management tool to guide the outline and detailed designs, and three business milestone reviews. 
- 'on-site' stage, denoting the period from the start of the site phase to the completion of the build phase. This stage included the main activities, e.g. pre-construction activities, management of sales and marketing campaigns, monitoring and management reporting, obtaining reservations and progressing sales, management of snagging.

- ' 'post-site' stage, denoting the two-year warranty period provided by the housebuilding company. After that, warranty is handed over to National House Building Council (NHBC) which is a leading warranty and insurance provider, covering over $80 \%$ new homes in the UK. Such practice is actually shared by most other large housebuilding firms in the UK. This stage included the main activities, e.g. the management of freehold interest, continuing marketing, selling and inspecting unsold properties, analysis of lessons learnt, customer satisfaction surveys, end project reviews, management of customer fault reporting, complaints and emergency call out and repair responsibilities.

(Insert Figure 1 here)

These four stages were primarily sequential, except that there were overlaps between 'land acquisition' and 'pre-site'. The stages reflected the 'whole-package' services that were provided by the company, i.e. from acquiring land, design, procurement, building, to postoccupancy, which is also a feature of most other large housebuilding firms in the UK. The results indicate that all the four stages were managed under corporate governance, guided by operational strategies and supported by business management processes and procedures.

Seven milestone reviews of the housebuilding business were also identified, as to the status of design and cost control of a typical housebuilding project in the UK. The milestone 
reviews mainly examined design and cost information, with risk management incorporated as well, and they were:

1) 'land pack', produced in the stage of 'land acquisition', denoting the business milestone review of initial design and development appraisal of the project.

2) 'planning pack', produced at the outset of the 'pre-site' stage, denoting the business milestone review of planning design and planning application of the project.

3) 'budget pack', produced in the middle of the 'pre-site' stage, denoting the business milestone review of tendering and contract award of the project.

4) 'start-on-site pack', produced in the end of the 'pre-site' stage, denoting the business milestone review of detailed design of the project.

5) 'five months into build', denoting the business milestone review of construction, sales and marketing activities.

6) 'six months after completion or three months after final legal completion', denoting the business milestone review of defects and customer satisfaction, and continuing sales and marketing activities.

7) 'two years warranty and then NHBC', denoting the business milestone review of the housebuilder's two-year warranty provision and then hand-over to NHBC.

These milestone reviews were observed to be fully integrated into the four key business stages of the housebuilding process. Underlying the management of the key business stages and milestone reviews were three hierarchical paradigms. They were at the three levels of organizational governance, i.e. corporate, cross subsidiary and department, and individual departmental levels.

- Corporate strategies were established and reviewed through several high-level mechanisms including ‘Corporate Management Committee’ (e.g. to approve all 
milestone reviews), ‘Chief Executive’s Advisory Group’, and 'Managing Directors’ Advisory Group’, which were organized on a bimonthly basis.

- Management decisions were supported by a number of cross-department, crosssubsidiary mechanisms including bimonthly ‘Technical Forum', 'Defects Forum’, ‘Supply Chain and Surveyors’ Forum’, and ‘Sustainability Working Group’ meetings.

- All the strategies and decisions were implemented at the operational level, facilitated by individual departmental functions and activities.

The three paradigms of organizational governance, contextualized in the four key stages and seven milestone reviews of the business process, provided a systemic business management structure of the firm. Such a system ensured business efficiency and managed risks that were associated with adopting less proven or new (to the firm) technology, and was considered to be effective by the participants in the study. However, it was commented that the system also introduced a barrier to take-up of other innovative technology and good practice, due to a perceived ‘lock-in’ effect to existing technology. While pro-active learning was observed in the company, organizational culture change was commonly raised to be difficult and painful.

\section{The integration of offsite into housebuilding business processes}

The company was committed to developing sustainable communities, and was open to the use of innovative and modern methods of construction in pursuit of this corporate goal. It aspired to improve business efficiency by standardizing design processes which involved the investigation into the use of offsite, and sought to learn from their previous experience. Despite the wide-ranging factors for considerations (previously reported by Pan et al. forthcoming), the principle for utilizing offsite technology was to improve business 
efficiency and manage risk for achieving long-term profitability. The integration of offsite production technology into the housebuilding business processes was investigated drawing on two detailed accounts of technology decision-making: one at the subsidiary firm level and the other at the project level.

Offsite integration: investigation at the firm level

The subsidiary firm level investigation revealed the people involved in the business process and their roles and responsibilities in relation to the use of building technology (i.e. to use or not to use offsite, if yes, which type of offsite technology to use for the specific project). All the main operational departments of the firm were examined, which included land, development, design, technical, estimating, buying, commercial (i.e. quantity survey), construction, health \& safety, and sales \& marketing.

- The land department was aware of offsite production technology, but such awareness was mainly introduced by the company’s commitment to developing sustainable communities and the high-profile (at the time) image of using modern methods of construction. Building technology was not, and was not considered to be, part of the decision equation for land acquisition.

- The development department was involved in the business process from the 'pre-site' stage, and was supposed to lead the project development and the associated milestone reviews. They were however observed still to be less concerned about the use of building technology (albeit more than that the land department expressed). The participants considered that the development department should be involved very early on in the business process, e.g. from basic house type design (in the stage of 'land acquisition') or outline planning application (in the stage of ‘land acquisition’ or 'presite’). 
- The design, technical, estimating and buying departments were engaged from the phase of basic house type design. The design department, in collaboration with the technical team, prepared the design proposal which specified the density of dwellings and the number of stories and units. Details of building technology (i.e. offsite or conventional building methods) were normally provided in such a proposal. The proposal was then verified by the estimating department through the activity of cost comparison. Despite heavy use of elemental cost comparison information, the firm had increasingly included non-cost benefit comparison (as either transferred cost items or qualitative benefits) and risk analysis in their building technology selection.

- During the process of verifying the design proposal and estimating, manufacturers, suppliers and subcontractors were normally approached through the managing buyer for providing commercial information. The commercial department was then involved from the 'pre-site' stage, with regard to tendering. A consensus was observed among the participants that specialist manufacturers, suppliers and subcontractors for offsite technology should be approached earlier than in verifying design and estimating, but in design development and possibly in outline design and planning application (in the stage of 'land acquisition' or 'pre-site'). Such earlier engagement was considered to be imperative to adopting more innovative and new (to the firm) offsite technology. However, some participants also commented that earlier engagement of supply chains was complex and could be problematic if not managed well. The main reasons for that were revealed to be concerns about uncertainties of planning and the housing market that were associated with urban regeneration schemes, as well as about a perceived lack of established supply chain for offsite technology in the UK.

- There appeared to be little involvement of the site construction team in the decisionmaking process of utilizing offsite technology, which however was not recognized by 
the other departments as presenting a problem. The departments of health \& safety and sales \& marketing also had little involvement in technology adoption, while they were considered to be important to feed back performance of different building systems (health \& safety, defects and snagging, respectively) to the other departments.

- The results indicate that it was the firm's Managing Director (MD) who fundamentally (i.e. encouraged and allowed effort to explore offsite) and eventually (i.e. finally approved the use of offsite) decided on the use of offsite technology for the project. However, the MD’s decision was heavily influenced and supported by the whole team.

A number of communication mechanisms were identified, which were used at the subsidiary firm level to support the adoption and utilization of offsite. These included: 'Intervention Meetings’ cross-departmental at the firm level; 'Project Development Meetings', still cross-departmental but with clearly established project teams; and sublevel mechanisms used by different departments, e.g. 'Subcontractors Meetings' called for by the buyers and the quantity surveyors and 'Construction Meetings' called for by the construction director.

To sum up the results of investigating offsite integration at the subsidiary firm level, all the operational departments had input into the technology decision process, albeit some taking championship while some others being expected to support to more extent. Despite the seemingly individual decision-making by the MD, the decision of offsite take-up was actually informed and shaped by the whole team. The decision was also evidential, albeit largely on cost and cost terms transferred from non-cost items. Nevertheless, there appeared to be potential of improving such decisions by engaging the supply chain earlier and more effectively. 
Offsite integration: investigation at the project level

The project-level investigation contextualized the investigation at the subsidiary firm level, and more importantly, revealed good practice and lessons learnt of integrating offsite in housebuilding. As explain in the research design, the two projects studied were both built by using precast concrete crosswall systems, while Project A involved the exploratory use of crosswall by the firm and Project B involved the established use of such technology. Both projects employed the same 'in-house' build team from the company, which minimized the bias of extracting learning from the practice.

For Project A, the decision to use crosswall technology was made very late in the design process. The original building design was in-situ reinforced concrete frame. The change of the construction solution was dramatic to the firm, which caused two months time loss in the design process and exposed the business to both technical and management risks. Two interconnected reasons for the delay were identified. First, there was a lack of knowledge of, and information on, crosswall technology in the subsidiary firm at the time, as it was its first use of such technology for multi-story buildings; hence such technology was not considered in the outline design stage. Secondly (consequently), the crosswall suppliers and specialist contractors were involved very late in the decision process, being just two months before the detailed design. In this case the crosswall technology was considered as a technical approach per se, simply a technical alternative to other well-tried conventional options (e.g. in-situ concrete frame). The integration of offsite into the housebuilding process in Project A was considered ad hoc and ineffective, rendering the benefit of utilizing offsite not fully realized. This experience added to the commitment of the 
company to review their business process in order to integrate offsite production more effectively.

Upon completion of Project B (2008), the subsidiary firm had constructed six projects using crosswall systems, which together included 12 multi-story residential buildings providing 880 apartments. For Project B, the firm continued using 'in-house’ build project management, and developed a partnership with the crosswall supplier and contractor, which covered the scope of services including not only manufacture, supply and installation, but also early involvement in building design and engineering. As a consequence, the technology was refined, e.g. using mast climbers instead of full external scaffold and aligning in-situ concrete for lower-floor commercial areas with up-floor residential areas by engineering the design, which helped achieve cost efficiency and effectiveness (see Pan and Sidwell 2011). Also, the firm built up an effective knowledge base of, and competent skills for, crosswall construction and offsite production. The utilization of offsite was clearly embedded in the organization's housebuilding business process and milestone reviews, which appeared to enable a virtuous circle of delivering projects successfully.

The project comparison indicates that the company had moved from the ad hoc individual project-based procurement of crosswall systems towards more organized, multi-project housebuilder-supplier relationships. The supply chain was involved in the housebuilder's early design stages for exploring technological innovations for repeatable multi-story buildings. The integration of offsite into housebuilding was enabled and managed through five offsite reviews (Figure 1). These offsite reviews, together with their associated main strategies, are summarized below: 
1) 'establish overall project offsite strategy'; the strategies included: check it is in line with company business strategy; appoint offsite champion and confirm project team commitment; agree project offsite targets and methods of measuring performance; ensure early supplier and manufacturer input is available; and confirm offsite strategy will be used on the project and is understood by all parties.

2) 'outline planning stages and detail design preparation'; the strategies included: review input of offsite champion and reinforce project team support; agree detailed offsite targets and criteria for measurement; ensure that any manufacturing process issues are addressed; and ensure that cost models are used to evaluate offsite for cost plan to include benefits realized outside of the specific element or non-cost benefits.

3) 'completion of coordinated design and preparation for manufacture'; the strategies included: review offsite targets and measurement; ensure project offsite strategy is followed; ensure that offsite strategy is not compromised by design development; ensure all project team members understand the manufacturing process and the effect of their decisions to maximize offsite opportunities; and ensure a thorough interface management strategy is applied, and that all parties are aware of their responsibilities.

4) 'completion of construction and preparation for two years after care'; the strategies included: review decisions taken earlier; review input of offsite champion and ensure feedback to other projects; complete full project review of offsite targets and measured results and ensure that effective feedback for future projects is achieved.

5) 'post-site reviews'; the strategies included: ensure performance of offsite units is measured effectively through the facilities management processes to assess their effectiveness; and ensure that performance data is fed back into future designs. 
The first three 'offsite reviews' ensure the establishment of an overall offsite strategy and the integration of offsite into outline and detailed design preparations. The last two 'offsite reviews' examine the decisions taken till the completion of construction, and ensure that measurements and feedback are captured for future designs.

\section{Good practice and learning of integrating the use of offsite}

The investigations at the corporate, subsidiary firm and project levels together revealed good practice and learning of integrating the use of offsite.

- First, the company realized the importance of regarding offsite production as a strategic approach to improving business efficiency, rather than an alternative construction technique per se, and therefore of integrating such an approach into early stages of the housebuilding process.

- Secondly, the learning of integrating and utilizing offsite methods was captured. The business encouraged organizational learning and information sharing to nurture an organizational culture embracing the adoption of offsite technology and innovation in a broader sense. However, organizational culture change was commonly perceived to be difficult and painful. The decision and communications mechanisms established in the company were observed to be useful to help the business and its personnel buy into the process of integrating offsite and promoting innovation. However, the mechanisms themselves, while helped improve efficiency, introduced extra reporting, commitment and management efforts, and therefore another layer of bureaucracy.

- Thirdly, offsite suppliers and contractors were consulted early in the design process, and their expertise, skills and experience, and relevant technical information were made available to the decision-makers of the company. However, earlier engagement of the supply chain was complex, and was inhibited by uncertainties of planning and the 
housing market, as well as a perceived lack of established supply chain for offsite technology in the UK.

- Fourthly, the company was committed to rationalizing their housing type designs that embrace standardization for efficiency and benchmark good practice. While these efforts increased repeatability of design and therefore favored the offsite approach, they inevitably demanded the company to make greater commitment to specific offsite supply chains, hence introduced a barrier to further development of other or more innovative technology. This was perceived to expose the business to risks associated with planning and market changes. In addressing such risks, the company developed an offsite supply chain database which included information of various types of offsite production technology (i.e. more than those having been utilized by the company). The company also maintained proactive discussions with wide-ranging offsite suppliers and contractors, which helped explore effective partnerships and mitigate market risks.

\section{Discussion}

The four key stages and seven milestone reviews of the housebuilding business process, together with the five offsite reviews, suggest a process framework for integrating the use of offsite production technology into housebuilding. The process aligns well with the phases of a typical construction project, e.g. as mapped in the 'Process Protocol' (Kagioglou et al. 1998). A key message of the process framework is to establish an overall offsite strategy in the 'land acquisition' stage or the early part of the 'pre-site' stage (e.g. outline design). Such a strategy will increase the likelihood of taking up offsite by housebuilding organizations and ensure the effectiveness of implementing such technology in the subsequent stages of the business process, and therefore introduces best opportunity for offsite integration (Figure 2). Such acknowledgement is supported by the claims of the 
prominence of land in UK large housebuilding business made in previous studies (e.g. Ball 2010; Barlow et al. 2003).

\section{(Insert Figure 2 here)}

Also, it is crucial to align the offsite reviews with the key stages of housebuilding or phases of construction (Figure 2). To ensure effectiveness and efficiency, these offsite reviews should be an organic part of the existing business reporting and management, rather than as an extra layer of bureaucracy. The strategies identified and examined in this research proved to be effective within the boundary of the case study company; however they may appear to be (over) prescriptive to other organizations. Therefore, while commending the process framework and the good practice and learning, this paper suggests further research into the strategies, drawing on the literature of construction process (e.g. RIBA 2008; Kagioglou et al. 1998) and offsite management guidelines (e.g. Gibb 2000; Gibb and Pendlebury 2005; Wilson et al. 1999). Cross case studies with other housebuilding companies should also help verify the findings. The results are further discussed below in the contexts of diverse business models, various offsite technologies and different countries.

\section{Diverse housebuilding business models}

The process framework and strategies were derived from the management practice of large private housebuilders which normally operate on the 'current trader' business model (Callcutt 2007), or ‘classic private housebuilder’ business model as referred to by Ball (2010). These companies are significant to UK housing supply, building more than two thirds of all new homes in the UK (Wellings 2006). Most of them take the role of developing and building homes, some supported by in-house design teams and partnered with their manufacturers and suppliers. However, as Venables et al. (2004) identified, 
some developers have no construction capability and subcontract the entire construction process. Therefore, it is important to highlight the significance of integrating offsite strategies in the overall project process for those developers and builders who are not directly involved in some of the project stages.

The successful experience of the housebuilder forming partnerships with their manufacturers and suppliers contributes evidence demonstrating the effectiveness of supply chain strategies developed in previous research (e.g. Hong-Minh et al. 2001; Naim and Barlow 2003) for shifting towards process orientation and responsiveness and improving efficiency and communications. Such movement for design standardization and efficiency seems to be explainable using the contractor-supplier relationship ideology identified by Hofman et al. (2009:41) that 'a significant dependence on a supplier’s investments and knowledge base combined with a moderate to low demand for variety lead to closer supplier integration'. However, the results of this study also suggest that greater commitment to specific supply chains will inevitably reduce the housebuilder's flexibility with their supply chain strategy and introduce risks associated with planning and market changes. This suggests offsite integration as a dichotomy, which is really attributable to the general perception that most UK private housebuilders largely elicit profit from land development rather than construction processes.

In addition to the different types of private housebuilders, there also exist some various business models in the UK housing sector. This includes those housebuilding companies which work with housing associations for social housing, and the self-built and developbuilt housing units which, according to Meikle (2008), account for at least $10 \%$ of private 
sector output. The process framework and strategies developed in this paper will need to be adapted to the various business specifics for effective implementation.

\section{Various offsite production technologies}

The case study company had utilized a range of offsite technologies, and the results of this study were obtained in that context. However, the two projects studied were built using precast concrete crosswall systems (a type of non-volumetric preassembly), which inevitably imposed the focus on such type of offsite technology of the investigation at the subsidiary firm and project levels. Gibb and Pendlebury (2006) suggested that offsite production technologies can be ranked against their associated degrees of offsite work, with an ascending order from component and subassembly, non-volumetric preassembly, volumetric preassembly to modular building. Technologies with higher degrees of offsite work (e.g. modular building) will more likely challenge the conventional housebuilding practice which largely employs site-based construction methods (see Roy et al. 2003). Therefore, greater attention is required in terms of integrating these offsite technologies into the housebuilding business process if their advantages are to be realized. In principle, the greater the extent of offsite work is, the earlier the key decisions must be taken and the sooner the client's design requirements must be frozen.

\section{Different countries}

The strategies centered on land acquisition were developed within the context of large private housebuilding in the UK. Care should be taken when interpreting the results in the context of housebuilding in some other countries where the linkages between contracting and housebuilding are much closer and the decoupling of housebuilding from land acquisition in new housing development is generally much clearer (Meikle 2008). This 
point is illustrated by the primary business strategy adopted in housebuilding elsewhere, for example, mass customization through innovation in production in Japan (Barlow and Ozaki 2005), volume house building based on cost leadership in Hong Kong (Chiang et al. 2008), and supply-contractor integration for modular house-building in the Netherlands (Hofman et al. 2009). Also, Ball (2008), drawing on an international comparison, concluded that UK housebuilding has a much higher degree of concentration than either Australia or the US, and attributed that to land planning dominance and market diversification of large firms in the UK.

\section{Conclusions}

Drawing on a critical survey of the literature and an action-research case study with a leading UK housebuilding company, this paper has scrutinized the processes through which offsite production technologies were adopted and utilized. The adoption and utilization of offsite was fundamentally framed by the four key stages of the housebuilding business process (i.e. 'land acquisition', 'pre-site', 'on-site’ and 'post-site’), and the seven business milestone reviews which concerned or were at the stages of 'land'; 'planning'; 'budget'; 'start on site’; '5 months into build'; ‘6 months after completion or 3 months after final legal completion'; and '2 years warranty and then hand-over to NHBC'. Five offsite reviews were aligned with and integrated into the processes, which ensured the establishment of offsite strategies and measurements and feedback captured for future designs. The stages, milestone reviews and offsite reviews together suggest a process framework for effectively integrating offsite technology into housebuilding, typically in the context of UK large housebuilding organizations.

Strategies for integrating the use of offsite technology are identified and examined. It was crucial to establish an overall offsite strategy and integrate it into the process from land 
acquisition on. Organizational learning and information sharing embraced the adoption of offsite technology, while extra reporting and management efforts introduced a layer of bureaucracy. Culture change was commonly perceived to be difficult and painful. Earlier engagement with supply chains was advocated for favoring the offsite approach and improving business efficiency, whilst it also demanded greater commitment of the housebuilder to specific supply chains and therefore exposed the business to risks associated with planning and market changes. The integration of offsite in UK housebuilding is therefore suggested as a dichotomy, reflecting the general perception that most UK private housebuilders mainly elicit profit from land development rather than construction processes. The strategies appeared to offer appropriate routes for better realizing the benefits of offsite production. The results derived from the scrutiny of the case study organization's management of offsite should contribute to breaking 'path dependency’ on the conventional construction system (Mahapatra and Gustavsson 2008), and guide the take-up of offsite technology in other organizations. However, the process framework and the strategies need adaptation for use in different contexts of business and technology, although they should generally facilitate building companies’ strategic management of offsite production technology.

\section{References}

Ball, M. (1996). Housing and Construction: A troubled relationship? The Policy Press, Bristol.

Ball, M. (2008). Firm size and competition: a comparison of the housebuilding industries in Australia, the United Kingdom and the USA, RICS, London.

Ball, M. (2010). The housebuilding industry: Promoting recovery in housing supply, CLG, London. 
Barker, K. (2003). Review of Housing Supply: Securing our Future Housing Needs, Interim Report - Analysis, HMSO, London.

Barlow, J., Childerhouse, P., Gann, D., Hong-Minh, S., Naim, M. and Ozaki, R. (2003). “Choice and Delivery in Housebuilding: Lessons from Japan for UK Housebuilders.” Building Research \& Information, 31(2), 134-45.

Barlow, J. and Ozaki, R. (2005). "Building mass customised housing though innovation in the production system: lessons from Japan.” Environment and Planning A, 37, 9-20.

Berg, B.L. (1998). Qualitative Research Methods for the Social Sciences, 4th edn. Allyn and Bacon, Boston.

BERR (2008). Strategy for Sustainable Construction, BERR, London.

Blismas, N.G. and Wakefield, R. (2009). "Drivers, constraints and the future of offsite manufacture in Australia.” Construction Innovation Special Issue on Offsite Manufacturing, 9(1), 72-83.

Bryman, A. (1989) Research Methods and Organization Studies, Unwin Hyman, London. Bryman, A. (2008). Social Research Methods. 3rd edn. Oxford University Press, Oxford.

Callcutt, J. (2007). The Callcutt Review of Housebuilding Delivery, CLG, London.

Chiang, Y., Tang, B. and Wong, F. (2008). "Volume building as competitive strategy." Construction Management and Economics, 26(February), 161-76.

CLG (2007). Building a Greener Future: Policy Statement, CLG, London.

Eastman, C. M. and Sacks, R. (2008). "Relative Productivity in the AEC Industries in the United States for On-Site and Off-Site Activities.” Journal of Construction Engineering and Management, 134(7), 517-526.

Gann, D. (1996). “Construction as a manufacturing process? Similarities and differences between industrialised housing and car production in Japan.” Construction Management and Economics, 14, 437-50. 
Gibb, A.G.F. (2000). Standardisation and Pre-assembly - Client's Guide and Toolkit, Construction Industry Research and Information Association (CIRIA), London.

Gibb, A.G.F. and Isack, F. (2003). “Re-engineering through pre-assembly: client expectations and drivers.” Building Research and Information, 31(2), 146-60.

Gibb, A.G.F. and Pendlebury, M.C. (2005). The CIRIA Offsite Project Toolkit. CIRIA, London.

Gibb, A.G.F. and Pendlebury, M.C. (2006). eds., Buildoffsite Glossary of Terms, Construction Industry Research \& Information Association (CIRIA), London.

Goodier, C.I. and Gibb, A.G.F. (2007). “Future opportunities for offsite in the UK.” Construction Management and Economics, 25, 585-95.

Goodier, C.I. and Pan, W. (2010). The Future of UK Housebuilding, RICS, London.

Green, S.D., Kao, C. and Larsen, G.D. (2010). “Contextualist Research: Iterating between Methods While Following an Empirically Grounded Approach.” Journal of Construction Engineering and Management, 136(1), 117-26.

Hofman, E., Voordijk, H. and Halman, J. (2009). “Matching supply networks to a modular product architecture in the house-building industry.” Building Research \& Information, 37(1), 31-42.

Hong-Minh, S.M., Barker, R. and Naim, M.M. (2001). "Identifying supply chain solutions in the UK house building sector.” European Journal of Purchasing \& Supply Management, 7(1), 49-59.

Housing Forum (2002). Homing in on excellence: A commentary on the use of off-site fabrication methods for the UK housebuilding industry, The Housing Forum, London. Jaillon, L. and Poon, C.S. (2009). “The evolution of prefabricated residential building systems in Hong Kong: A review of the public and the private sector.” Automation in Construction, 18, 239-48. 
Kadir, M.R.A., Lee, W.P., Jaafar, M.S., Sapuan, S.M. and Ali, A.A.A. (2006).

“Construction performance comparison between conventional and industrialised building systems in Malaysia.” Structural Survey, 24(5), 412-24.

Kagioglou, M., Cooper, R. and Aouad, G. (1998). A generic guide to the design and construction process protocol, University of Salford, Salford.

Koshy, V. (2005) Action Research for Improving Practice: A Practical Guide, Paul Chapman Publishing, London.

Larsson, B., Sundqvist, J. and Emmitt, S. (2006). “Component manufacturers’ perceptions of managing innovation.” Building Research \& Information, 34(6), 552-64.

Mahapatra, K. and Gustavsson, L. (2008). “Multi-storey timber buildings: breaking industry path dependency.” Building Research \& Information, 36(6), 638-48.

Meikle, J. (2008). “UK housebuilding.” Building Research \& Information, 36(2), 200-2

Miles, M.B. and Huberman, A.M. (1994). Qualitative data analysis: An expanded sourcebook. London: Sage.

Mullens, M. A. and Arif, M. (2006). “Structural Insulated Panels: Impact on the Residential Construction Process.” Journal of Construction Engineering and Management, 132(7) 786-794.

Naim, M. and Barlow, J. (2003). “An innovative supply chain strategy for customized housing.” Construction Management and Economics, 21, 593-602

Pan, W, Gibb, A.G.F. and Dainty, A.R.J. (2007). "Perspectives of housebuilders on the use of offsite Modern Methods of Construction.” Construction Management and Economics, 25(2), 183-94.

Pan, W, Gibb, A.G.F. and Dainty, A.R.J. (2008). “Leading UK housebuilders’ utilization of offsite construction methods.” Building Research \& Information, 36(1), 56-67. 
Pan, W. and Goodier, C.I. (2012) Housebuilding business models and offsite construction take-up. ASCE Journal of Architectural Engineering, In press, doi:10.1061/(ASCE)AE.1943-5568.0000058.

Pan, W., Dainty, A.R.J. and Gibb, A.G.F. (forthcoming) Establishing and Weighting Decision Criteria for Building System Selection in Housing Construction. Journal of Construction Engineering and Management.

Pan, W. and Sidwell, R. (2011) Demystifying the Cost Barriers to Offsite Construction in the UK. Construction Management and Economics, 29(11), 1081-1099.

Parry, T., Howlett, C. and Samuelsson-Brown, G. (2003). Off Site Fabrication: UK Attitudes and Potential, Report 17356/1, BSRIA, Bracknell.

RIBA (2008). Plan of Work: Multi-Disciplinary Services, RIBA, London.

Roy, R., Brown, J. and Gaze, C. (2003). "Re-engineering the construction process in the speculative house-building sector.” Construction Management and Economics, 21(2), 137-46.

Roy, R, Low, M and Waller, J. (2005). “Documentation, standardisation and improvement of the construction process in house building." Construction Management and Economics, 23(1), 57-67.

Sacks, R., Eastman, C. M. and Lee, G. (2004). "Process Model Perspectives on Management and Engineering Procedures in the Precast/Prestressed Concrete Industry.” Journal of Construction Engineering and Management, 130(2), 206-215.

Silverman, D. (2005). Doing Qualitative Research: A practical handbook, 2nd edn. Sage, London.

Song, J., Fagerlund, W. R., Haas, C. T., Tatum, C. B. and Vanegas, J. A. (2005). “Considering Prework on Industrial Projects.” Journal of Construction Engineering and Management, 131(6), 723-733. 
Sparksman, G., Groak, S., Gibb, A.G.F. and Neale, R. (1999). Standardisation and Preassembly: Adding Value to Construction Projects, CIRIA, London.

Taylor, M. D. (2010). “A definition and valuation of the UK offsite construction sector.” Construction Management and Economics, 28, 885-896.

Taylor, J. E., Dossick, C. S. and Garvin, M. (2011) Meeting the Burden of Proof with Case-Study Research. Journal of Construction Engineering and Management, 137(4), 303-311.

TSO (2010). Spending Review 2010, The Stationery Office (TSO), Norwich.

Van de Ven, A.H. (2007) Engaged Scholarship: A Guide for Organizational and Social Research, Oxford University Press, Oxford.

Venables, T. and Courtney, R. (2004). Modern methods of construction in Germanyplaying the off-site rule. Report of a DTI Global Watch Mission. DTI: London.

Venables, T., Barlow, J. and Gann, D. (2004). Manufacturing Excellence: UK Capacity in Offsite Manufacturing, The Housing Forum, London.

Wellings, F. (2006). Private Housebuilding Annual 2006, The Builder Group, London.

Wilson, D.G, Smith, M.H and Deal, J. (1999). Prefabrication and Preassembly - applying the techniques to building engineering services. Building Services Research and Information Association (BSRIA), Bracknell.

Yin, R.K. (2003). Case Study Research: Design and Methods. $3^{\text {rd }}$ edn. Thousand Oaks: Sage. 
Table 1 Details of the case study projects

\begin{tabular}{|c|c|c|}
\hline & Project A & Project B \\
\hline Dwelling type & $\begin{array}{l}102 \text { units of } 1 \text { and } 2 \text { bedroom } \\
\text { apartments }\end{array}$ & $\begin{array}{l}152 \text { units of } 1 \text { and } 2 \text { bedroom } \\
\text { apartments }\end{array}$ \\
\hline Location & East Manchester, UK & Salford, UK \\
\hline Structure & $\begin{array}{l}\text { Block 1, } 9 \text { stories; Block 2, } 7 \\
\text { stories }\end{array}$ & One block, 9 stories \\
\hline Year of completion & 2004 & 2008 \\
\hline Offsite technology & $\begin{array}{l}\text { PCC }{ }^{a} \text { crosswall }{ }^{b} \text { panels } \\
\text { (external \& party walls), PCC } \\
\text { floor planks, with full external } \\
\text { scaffold }\end{array}$ & $\begin{array}{l}\text { PCC crosswall panels (external } \\
\text { \& party walls), PCC floor } \\
\text { planks, with no external scaffold } \\
\text { (using mast climbers) }\end{array}$ \\
\hline Offsite experience & $\begin{array}{l}\text { The } 1^{\text {st }} \text { crosswall multi-story } \\
\text { building project within the } \\
\text { company }\end{array}$ & $\begin{array}{l}\text { The } 6^{\text {th }} \text { crosswall multi-story } \\
\text { building project within the } \\
\text { company }\end{array}$ \\
\hline Procurement & $\begin{array}{l}\text { In-house build for project } \\
\text { management, fixed price } \\
\text { package for subcontracting }\end{array}$ & $\begin{array}{l}\text { In-house build for project } \\
\text { management, partnering style } \\
\text { procurement for crosswall }\end{array}$ \\
\hline $\begin{array}{l}\text { Specialist contract } \\
\text { services }\end{array}$ & $\begin{array}{l}\text { Manufacture, supply and } \\
\text { installation }\end{array}$ & $\begin{array}{l}\text { Manufacture, supply and } \\
\text { installation, as well as early } \\
\text { building design involvement and } \\
\text { design engineering }\end{array}$ \\
\hline
\end{tabular}

\footnotetext{
${ }^{\mathrm{a}}$ PCC: Pre-cast Concrete

${ }^{b}$ Crosswall: an offsite method of building construction using a series of precast concrete division or party walls which transfer the floor loads through the building to foundation
} 
Figure 1 Map of housebuilding business process \& integrated offsite reviews

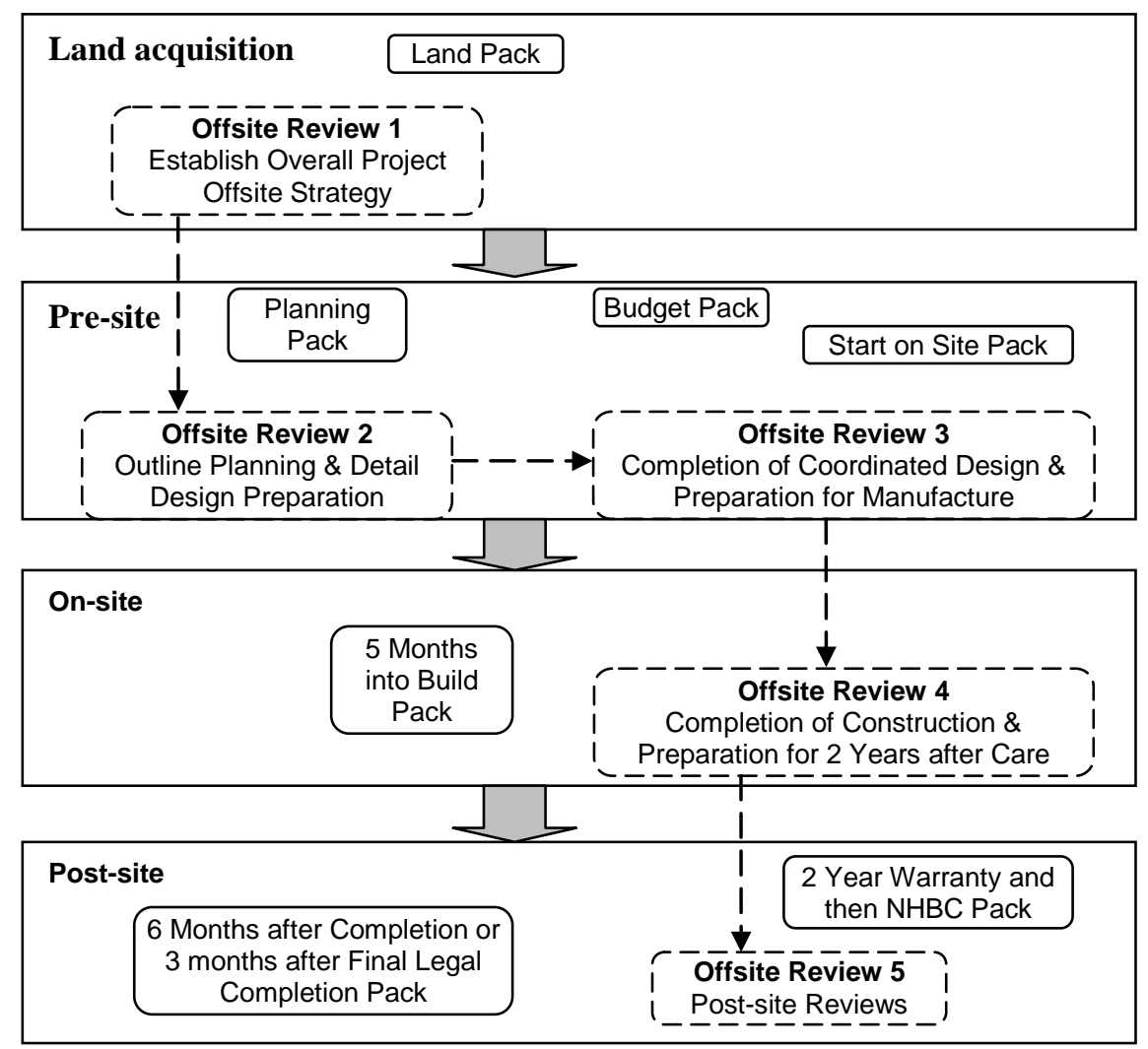

Note: The solid line boxes represent the four key stages and seven milestone reviews of the housebuilding business; the dotted line boxes represent the five offsite reviews. 
Figure 2 Timing of opportunity for integrating the use of offsite technology

\begin{tabular}{|c|c|c|c|c|c|c|c|c|c|c|c|}
\hline \multirow{3}{*}{$\begin{array}{l}\text { Stages of } \\
\text { housebuilding } \\
\text { Phases of a } \\
\text { typical } \\
\text { construction } \\
\text { project }\end{array}$} & \multicolumn{7}{|c|}{ Land acquisition } & \multicolumn{2}{|c|}{ Pre-site } & \multirow{2}{*}{$\begin{array}{l}\text { On- } \\
\text { site }\end{array}$} & \multirow{2}{*}{$\begin{array}{l}\text { Post- } \\
\text { site }\end{array}$} \\
\hline & \multicolumn{2}{|c|}{ Opportunity } & \multicolumn{2}{|c|}{$\begin{array}{c}\text { Viability } \\
\text { appraisal }\end{array}$} & \multicolumn{3}{|c|}{ Proposals } & & & & \\
\hline & 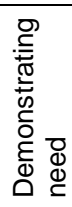 & 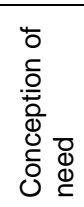 & 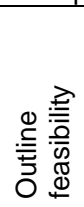 & 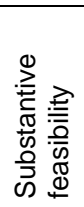 & 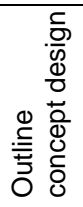 & 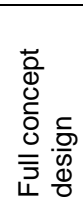 & 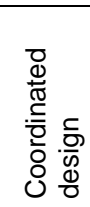 & 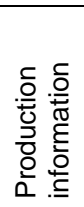 & 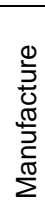 & 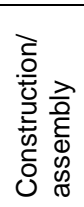 & 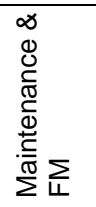 \\
\hline $\begin{array}{l}\text { Offsite reviews \& } \\
\text { integration }\end{array}$ & & $\begin{array}{r}\text { Offs } \\
\text { Revic } \\
\end{array}$ & & & & & $\begin{array}{l}\text { Dffsite } \\
\text { eview } 2\end{array}$ & $\begin{array}{r}\text { Offsite } \\
\text { Review }\end{array}$ & & $\begin{array}{r}7 \\
\text { Offs } \\
\text { Revie }\end{array}$ & \\
\hline & & $\begin{array}{l}\text { Best o } \\
\text { offsite }\end{array}$ & $\begin{array}{l}\text { ortunity } \\
\text { egratio }\end{array}$ & & & & & & & & \\
\hline
\end{tabular}

